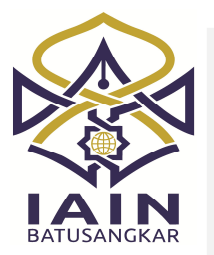

\title{
Cooperative Learning Strategy Type STAD in Teaching Islamic Education Subject $(P A I)$ at Smpn 3 Lengayang
}

\author{
Zulvia Trinova *) \\ Universitas Islam Negeri Imam Bonjol \\ Padang, Sumatera Barat, Indonesia \\ E-mail: zulvia.trinova12@gmail.com
}

\section{Sri Dalena*}

Universitas Islam Negeri Imam Bonjol

Padang, Sumatera Barat, Indonesia E-

mail: sri_dalena@yahoo.com

\begin{abstract}
Abstrak: SMPN 3 Lengayang has applied STAD as a type of cooperative learning to improve students' passiveness. The learning is initiated by forming study groups and assigning tasks to be discussed together. However, in fact the learning is not effective that the students still can not understand the materials properly. It is noticable that the tasks given have been done by one student only, meanwhile the others are less serious and rely on those who are willing to do the group work. This is a field reasearch which describes the implementation of STAD in teaching PAI qualitatively. Data collection techniques used are in the form of observation, interviews, and documentation. As the result; 1) the planning of STAD strategy in teaching $P A I$ at SMPN 3 Lengayang does not yet fulfill the requirement such as in organizing teaching materials (systematic/systematic demands with unsuitable time allocation), and detail of learning scenario (strategy step / method at each stage not clearly illustrated). 2) the implementation of STAD type in teaching PAI at SMPN 3 Lengayang is not fully implemented from the six STAD type cooperative learning steps, namely on teamwork and quiz, and 3) the evaluation in STAD type co-operative learning at SMPN 3 Lengayang is a written test or in the form of quiz. In addition, a test through a special quiz for individual assessment while group assessment is taken from group work. Especially the group with the highest score is given an additional mark.
\end{abstract}

Kata Kunci: Strategy, Cooperative Type STAD, Teaching Islamic Education (PAI)

\section{PENDAHULUAN}

Manusia dan pendidikan tidak dapat dipisahkan, sebab pendidikan merupakan kunci dari masa depan manusia yang dibekali akal dan pikiran. Pendidikan mempunyai peranan penting untuk menjamin perkembangan dan kelangsungan hidup suatu bangsa. Karena pendidikan merupakan suatu wahana untuk meningkatkan kualitas sumber daya manusia. Kebutuhan pendidikan merupakan hak asasi setiap manusia, menurut Undang-Undang RI nomor 20 tahun 2003 tentang sistem pendidikan nasional bab I pasal I.

Pendidik memiliki posisi yang sangat menentukan keberhasilan pembelajaran dalam kegiatan belajar mengajar. guru dan proses pembelajaran merupakan dua hal yang memiliki keterkaitan yang sangat erat dan mutlak, artinya guru akan lebih memiliki makna secara edukatif jika guru itu mampu melakukan proses pembelajaran yang baik, tepat, akurat serta relevan dengan fungsi dan prinsip pendidikan, ini merupakan tantangan bagi para pendidik. Bila selama ini proses pembelajaran kebanyakan hanya ditandai kegiatan satu arah penuangan informasi dari guru kepada siswa. Maka sebagai penggerak dalam pembelajaran guru harus mampu menciptakan dan melaksanakan strategi 
dalam proses pembelajaran yang dapat merangsang keaktifan siswa.

Dalam pelaksanaan pembelajaran, guru diharapkan bisa menerapkan strategi pembelajaran seperti apa yang dibutuhkan dalam proses pembelajaran di kelas. Bagaimana bagus dan ideal kurikulum pendidikan, bagaimana lengkapnya sarana dan prasarana pendidikan tanpa diimbangi dengan kemampuan guru mengimplementasikan, maka semuanya akan kurang bemakna. Strategi pembelajaran sangat berguna bagi guru dan siswa. Bagi siswa strategi bermanfaat untuk membangkitkan motivasi belajar.

Motivasi merupakan salah satu aspek dinamis yang sangat penting, motivasi belajar merupakan kekuatan mental yang mendorong terjadinya proses belajar. Motivasi belajar pada siswa dapat menjadi lemah, lemahnya motivasi atau tiadanya motivasi belajar akan melemahkan motivasi kegiatan belajar (Sanjaya, 2008: 240). Tanpa adanya motivasi belajar siswa yang tinggi, maka guru akan sulit untuk mencapai hasil pembelajaran yang optimal. Untuk bisa menumbuhkan, menjaga dan meningkatkan motivasi belajar siswa agar mendapat hasil belajar yang maksimal, guru bisa menerapkan strategi pembelajaran kooperatif.

Strategi pembelajaran kooperatif merupakan suatu strategi pembelajaran yang mengutamakan adanya kelompokkelompok. Setiap siswa yang ada dalam kelompok mempunyai tingkat kemampuan yang berbeda (tinggi, rendah, sedang). Strategi pembelajaran kooperatif mengutamakan kerjasama dalam menyelesaikan permasalahan untuk menerapkan pengetahuan dan keterampilan dalam rangka mencapai tujuan pembelajaran. Strategi pembelajaran kooperatif adalah salah satu strategi pembelajaran yang dapat meningkatkan aktivitas siswa, meningkatkan daya nalar, aktif, kreatif, dan terbuka. Selain itu, strategi ini mampu meningkatkan penguasaaan siswa terhadap materi pembelajaran dan akan meningkatkan motivasi siswa untuk aktif dalam proses pembelajaran.

Ada tiga pernyataan sederhana yang menyatakan perlunya cara belajar aktif yaitu yang saya dengar saya lupa, yang saya lihat saya ingat, dan yang saya kerjakan saya pahami. Apabila siswa mempergunakan pendengaran, penglihatan dan mengerjakan tentunya pelajaran yang diterima lebih lama ingatnya (Silberman, 2006: 23). Dengan demikian, guru perlu memperhatikan gaya belajar masing-masing siswa, sehingga berdasarkan gaya belajarnya masing-masing, maka guru dapat menentukan strategi pembelajaran yang akan diterapkan dalam menyampaikan materi pelajaran, dan satu di antaranya adalah strategi pembelajaran kooperatif.

Menurut Sanjaya (2008: 239) ada empat unsur penting dalam strategi pembelajaran kooperatif yaitu:

1. Adanya peserta dalam kelompok Siswa yang melakukan proses pembelajaran dalam kelompok belajar, pengelompokkan siswa bisa diterapkan berdasarkan bakat atau latar belakang kemampuan.

2. Aturan kelompok

Segala sasuatu yang menjadi kesepakatan semua pihak (siswa) seperti pembagian tugas setiap kelompok.

3. Upaya belajar setiap anggota kelompok, adalah segala aktivitas siswa untuk meningkatkan kemampuan.

4. Tujuan yang harus dicapai

Strategi pembelajaran kooperatif memiliki banyak tipe salah satunya adalah STAD (Student Teams-Achievement Division). Dalam STAD, siswa dibagi menjadi kelompok beranggotakan empat atau lima orang yang beragam kemampuan, jenis kelamin, dan sukunya. Guru memberikan suatu pelajaran dan siswa-siswa dalam kelompok memastikan 
bahwa semua anggota kelompok itu menguasai pelajaran tersebut. Akhirnya semua siswa menjalani kuis perseorangan tentang materi tersebut, dan pada saat itu mereka tidak boleh saling membantu satu sama lain. Nilai-nilai kuis siswa diperbandingkan dengan nilai rata-rata mereka sendiri yang diperoleh sebelumnya dan nilai itu diberi hadiah berdasarkan pada seberapa tinggi peningkatan mereka capai. Kelompok yang mencapai kriteria tertentu mendapat hadiah. Menurut Slavin, gagasan utama di belakang STAD adalah memacu siswa agar saling mendorong dan membantu satusama lain untuk menguasai keterampilan yang diajarkan guru (Rusman, 2011: 214). Dengan diterapkannya Strategi pembelajaran kooperatif tipe STAD ini, maka dapat membuat siswa memiliki banyak kemampuan dan keterampilan dalam pembelajaran, termasuk dalam pembelajaran PAI yang memiliki berbagai bidang studi, seperti akidah akhlak.

Pembelajaran PAI dengan tema akidah, akhlak dan beribadah dinilai dapat membentuk karakter siswa, membuat mental muslim kuat dan tegar menjalankan cobaan dalam kehidupan. Hal ini akan tercapai bila pembelajaran PAI dilakukan dengan menyentuh aspek kognitif, psikomotorik, dan afektif. Untuk mencapai hal itu diperlukan pembelajaran aktif yang membantu untuk mempelajari sesuatu dengan baik.

Namun, berdasarkan pengalaman riil di lapangan, proses pembelajaran di sekolah dewasa ini kurang meningkatkan kreativitas siswa, terutama dalam pembelajaran PAI. Masih banyak tenaga pendidik yang menggunakan metode konvensional secara monoton sehingga pembelajaran di kelas terkesan kaku dan didominasi oleh guru. Dalam penyampaian materi, biasanya siswa hanya duduk mencatat dan mendengar apa yang disampaikan guru. Penuangan satu arah dalam situasi belajar mengajar menimbulkan yang berbeda. Disatu pihak ini menjadikan siswa pasif, hal demikian hanya cendrung memproduksi apa yang mereka dapatkan dari guru sehingga dapat menyebabkan pengembangan ilmu menjadi lambat.

Untuk mengatasi hal tersebut, guru sebagai komponen utama dalam pendidikan diharapkan mampu melaksanakan strategi dengan tepat. Salah satunya dengan menerapkan pembelajaran kooperatif. Secara tidak langsung penerapan pembelajaran kooperatif ini telah menanamkan konsep PAI pada anak yaitu konsep saling tolong menolong. Hal ini sesuai dengan firman Allah SWT dalam surat Al-Maidah yang berbunyi:

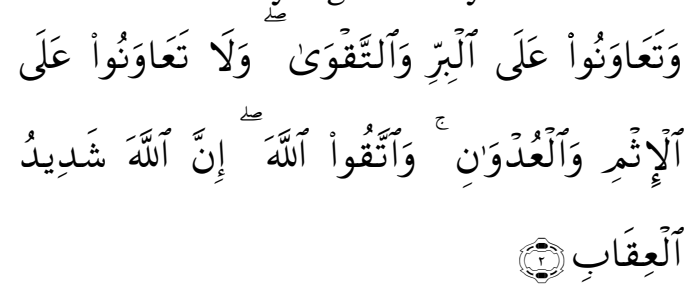

Dan tolong-menolonglah kamu dalam (mengerjakan) kebajikan dan takwa, dan jangan tolong-menolong dalam berbuat dosa dan pelanggaran. dan bertakwalah kamu kepada Allah, Sesungguhnya Allah Amat berat siksaNya”.(Q.S. Al-Maidah: 2).

Menurut Hamka dalam tafsir AlAzhar kalimat "tolong menolonglah kamu dalam kebajikan dan takwa" maksudnya adalah Allah menganjurkan dan memberi peringatan supaya hidup tolong-menolong dalam melakukan pekerjaan-pekerjaan yang baik. Banyak pekerjaan kebajikan yang dapat dipikul sendiri dengan tolong menolong baru lancar, seperti mendirikan mesjid, sekolah, mengatur pendidikan kanak-kanak, dan menuntut ilmu. Ibarat kata berat sama dipikul ringan sama dijinjing. Tolong menolong yang dimaksud disini hanya untuk hal yang berfaedah yang didasari kepada menegakkan takwa yaitu mempererat hubungan dengan Tuhan (Hamka, 1983: 112). 
SMPN 3 Lengayang merupakan salah satu sekolah menengah yang banyak diminati. SMPN 3 Lengayang pun sudah mulai menerapkan pembelajaran aktif untuk meningkatkan aktivitas belajar siswa. Sebagian gurunya sudah ada yang menerapkan pembelajaran kooperatif, di antaranya guru agama dalam memberikan materi pelajaran akidah akhlak dan fikih.

Guru agama tersebut berusaha untuk meningkatkan kualitas belajar siswa dari kebiasaan belajar pasif menjadi aktif, yaitu dengan membentuk kelompok belajar. Tapi tidak dipungkiri dengan segala upaya yang dilakukan oleh guru tersebut, siswa masih juga belum dapat memahami dengan benar materi yang diberikan sesuai yang diharapkan guru, hanya $33 \%$ siswa yang benar-benar menunjukkan partisipasi. Hal ini terlihat dari adanya siswa yang kurang serius dalam mengikuti pelajaran dan siswa yang mengandalkan temannya terutama dalam kerja kelompok. Padahal gagasan utama dari STAD adalah untuk memotivasi siswa supaya dapat saling mendukung dan membantu satusama lain dalam menguasai kemampuan yang diajarkan oleh guru dan bisa meningkatkan hasil belajar.

\section{PEMBAHASAN}

\section{Strategi Pembelajaran Kooperatif}

Pembelajaran kooperatif merupakan suatu strategi pembelajaran yang akhirakhir ini menjadi perhatian bagi seorang pendidik, karena adanya harapan selain memiliki dampak pembelajaran yaitu berupa peningkatan prestasi belajar peserta didik juga dampak penggiring seperti relasi sosial, penerimaan terhadap peserta didik yang dianggap lemah, dan suka memberi pertolongan kepada orang lain. Pembelajaran kooperatif bernaung dalam teori konstruktivis, pembelajaran ini muncul dari konsep bahwa siswa akan lebih mudah menemukan dan memahami konsep yang sulit jika mereka saling berdiskusi dengan temannya. Siswa secara rutin bekerja dalam kelompok untuk saling membantu memecahkan masalah-masalah yang kompleks.

Pada dasarnya strategi pembelajaran kooperatif merupakan strategi pembelajaran dengan menggunakan sistem pengelompokan atau tim kecil, yaitu antara empat sampai enam orang yang mempunyai latar belakang, kemampuan akademik, jenis kelamin, ras atau suku yang berbeda (heterogen). Sistem penilaian dilakukan terhadap kelompok, setiap kelompok akan memperoleh penghargaan (reward), jika kelompok mampu menunjukkan prestasi yang dipersyaratkan. Dengan demikian, setiap anggota kelompok akan mempunyai ketergantungan positif.

\section{Pembelajaran Kooperatif tipe STAD (Student Teams-Achievement Division)}

Tipe STAD dikembangkan oleh Robert Slavin dan teman-temannya di Universitas John Hopkin. Pembelajaran kooperatif tipe STAD merupakan strategi pembelajaran koooperatif yang paling sederhana dan merupakan strategi yang paling baik untuk permulaan bagi guru yang baru menggunakan strategi kooperatif. Guru yang menggunakan tipe STAD mengacu kepada belajar kelompok siswa, menyajikan informasi akademik baru kepada siswa, dan setiap minggu menggunakan presentasi verbal atau teks (Rusman, 214)

Dalam tipe STAD, siswa dibagi menjadi kelompok beranggotakan empat sampai enam orang yang beragam kemampuan, jenis kelamin, dan sukunya. Guru memberikan suatu pelajaran dan siswa-siswa dalam kelompok memastikan bahwa semua anggota kelompok bisa menguasai pelajaran tersebut. Akhirnya semua siswa menjalani kuis perseorangan tentang materi tersebut, dan pada saat itu mereka tidak boleh saling membantu satusama lain. Nilai-nilai hasil kuis siswa diperbandingkan dengan nilai rata-rata 
mereka sendiri yang diperoleh sebelumnya. Nilai itu diberi hadiah berdasarkan pada seberapa tinggi peningkatan yang bisa mereka capai atau seberapa tinggi nilai itu melampaui nilai mereka sebelumnya. Slavin menyatakan bahwa gagasan utama di belakang pembelajaran kooperatif tipe STAD adalah memacu siswa agar saling mendorong dan membantu satu sama lain untuk menguasai keterampilan yang diajarkan guru (Slavin, 2005: 143-144).

Pembelajaran kooperatif tipe STAD terdiri atas lima komponen utama, yaitu:
a. Presentasi Kelas
b. Tim
c. Kuis
d. Skor Kemajuan Individual
e. Rekognasi tim

Setelah masing-masing anggota kelompok bekerja dalam timnya dan setelah diadakan kuis, supaya kelompok mendapat penghargaan maka tugas anggota kelompok berlomba untuk meningkatkan skor kemajuan masingmasing untuk disumbangkan pada skor kelompok. Agar siswa dapat menjawab kuis dengan baik, maka harus fokus pada penjelasan guru sebelumnya.

Langkah langkah tipe STAD (1) Penyampaian tujuan dan motivasi, Pembagian Kelompok; (2) Presentasi dari guru, (3) Kegiatan belajar dalam tim (Kerja tim), (4) Kuis (Evaluasi) (Rusman, 215), (5) Penghargaan prestasi tim.

Setelah pelaksanaan kuis, guru memeriksa hasil kerja siswa dan diberikan angka dengan rentang 0-100. Selanjutnya pemberian penghargaan atas keberhasilan kelompok dapat dilakukan oleh guru dengan melakukan tahapan-tahapan sebagai berikut:

Menghitung Skor Individu

Menurut Slavin (Trianto, 2007: 55) untuk menghitung perkembangan skor individu dihitung sebagaimana dapat dilihat pada tabel berkut:
Tabel 1

Skor Perkembangan Individu

\begin{tabular}{|c|c|c|}
\hline No & Nilai Tes & $\begin{array}{c}\text { Skor } \\
\text { Perkemb } \\
\text { angan }\end{array}$ \\
\hline $\begin{array}{l}1 \\
2 \\
3 \\
4 \\
5\end{array}$ & $\begin{array}{l}\text { Lebih dari } 10 \text { poin di } \\
\text { bawah skor dasar } \\
10 \text { sampai } 1 \text { poin di } \\
\text { bawah skor dasar } \\
\text { Skor 0 sampai } 10 \text { poin di } \\
\text { atas skor dasar } \\
\text { Lebih dari } 10 \text { poin di atas } \\
\text { skor dasar } \\
\text { Pekerjaan sempurna } \\
\text { (tanpa memerhatikan } \\
\text { skor dasar) }\end{array}$ & $\begin{array}{l}0 \text { poin } \\
10 \text { poin } \\
20 \text { Poin } \\
30 \text { Poin } \\
30 \text { oin }\end{array}$ \\
\hline
\end{tabular}

Menghitung Skor Kelompok

Skor kelompok dihitung dengan

membuat rata-rata skor perkembangan anggota kelompok, yaitu dengan menjumlahkan semua skor perkembangan individu anggota kelompok dan membagi sejumlah anggota kelompok tersebut. Sesuai dengan rata-rata skor perkembangan kelompok, seperti tabel berikut:

Tabel 2

\section{Skor Kelompok}

\begin{tabular}{|l|l|l|}
\hline No & \multicolumn{1}{|c|}{$\begin{array}{c}\text { Rata-rata } \\
\text { skor }\end{array}$} & \multicolumn{1}{c|}{ Kualifikasi } \\
\hline 1. & $0<\mathrm{N}<5$ & - \\
2. & $6<\mathrm{N}<15$ & $\begin{array}{l}\text { Tim yang baik (Good } \\
\text { team) } \\
\text { Tim yang baik sekali } \\
\text { (Great team) } \\
\text { Tim yang istimewa } \\
\text { (super team) }\end{array}$ \\
\hline
\end{tabular}

Pemberian hadiah dan pengakuan skor kelompok

Setelah masing-masing kelompok atau tim memperoleh predikat. Guru memberikan hadiah atau penghargaan kepada masing-masing kelompok sesuai dengan prestasinya (Trianto, 72).

$$
\text { Adapun langkah-langkah }
$$

pembelajaran kooperatif tipe STAD ini seperti tersaji dalam tabel berikut: 
Tabel 3

Fase-fase Pembelajaran

Kooperatif tipe STAD

\begin{tabular}{|c|c|}
\hline Fase & Kegiatan Guru \\
\hline $\begin{array}{l}\text { Fase } 1 \\
\text { Menyampaikan } \\
\text { tujuan dan } \\
\text { memotivasi } \\
\text { siswa }\end{array}$ & $\begin{array}{l}\text { Menyampaikan } \\
\text { semua tujuan } \\
\text { pembelajaran yang } \\
\text { dicapai pada } \\
\text { pelajaran tersebut dan } \\
\text { memotivasi siswa } \\
\text { belajar }\end{array}$ \\
\hline $\begin{array}{l}\text { Fase } 2 \\
\text { Menyajikan/men } \\
\text { yampaikan } \\
\text { informasi }\end{array}$ & $\begin{array}{l}\text { Menyajikan } \\
\text { informasi kepada } \\
\text { siswa dengan jalan } \\
\text { mendemonstrasikan } \\
\text { atau lewat daftar } \\
\text { bacaan }\end{array}$ \\
\hline $\begin{array}{l}\text { Fase } 3 \\
\text { Mengorganisasi } \\
\text { siswa dalam } \\
\text { kelompok- } \\
\text { kelompok belajar }\end{array}$ & $\begin{array}{l}\text { Menjelaskan kepada } \\
\text { siswa bagaimana } \\
\text { caranya membentuk } \\
\text { kelompok belajar dan } \\
\text { membantu setiap } \\
\text { kelompok agar } \\
\text { melakukan transisi } \\
\text { secara efisien }\end{array}$ \\
\hline $\begin{array}{l}\text { Fase } 4 \\
\text { Membimbing } \\
\text { kelompok } \\
\text { bekerja dan } \\
\text { belajar } \\
\end{array}$ & $\begin{array}{l}\text { Membimbing } \\
\text { kelompok belajar } \\
\text { pada saat mereka } \\
\text { mengerjakan tugas }\end{array}$ \\
\hline $\begin{array}{l}\text { Fase } 5 \\
\text { Evaluasi }\end{array}$ & $\begin{array}{l}\text { Mengevaluasi hasil } \\
\text { belajar tentang materi } \\
\text { yang telah diajarkan } \\
\text { atau masing-masing } \\
\text { kelompokmempresen } \\
\text { tasikan hasil kerjanya }\end{array}$ \\
\hline $\begin{array}{l}\text { Fase } 6 \\
\text { Memberikan } \\
\text { penghargaan }\end{array}$ & $\begin{array}{l}\text { Mencari cara-cara } \\
\text { untuk menghargai } \\
\text { baik upaya maupun } \\
\text { hasil belajar individu } \\
\text { dan kelompok }\end{array}$ \\
\hline
\end{tabular}

\section{Pendidikan Agama Islam}

Pengertian pendidikan Islam secara umum ada tiga istilah yang dipakai untuk menggambarkan pengertian pendidikan Islam, yaitu "al tarbiyah, al ta'lim, dan at ta'dib. Ketiga istilah ini memiliki perbedaan pengertian dikalangan tokoh pendidikan Islam.
Kata al Tarbiyah dapat diartikan sebagai kegiatan membimbing anak didik dengan bimbingan yang sebaik-baiknya dan merawat serta memperhatikan pertumbuhan badannya yaitu dengan cara memberikan gizi yang baik, di samping itu juga mengarahkan dan membina akhlak memiliki kepribadian yang utama.

Kata al Ta'lim lebih menitikberatkan pengertian pendidikan dalam arti penyampaian ilmu pengetahuan kepada peserta didik (transfer of knowledge). Kata at Ta'dib merupakan masdar dari kata addaba yang dapat diartikan kepada proses pembinaan kepribadian dan sikap moral (afektif) dan etika dalam kehidupan sehari-hari.

Adapun pengertian pendidikan Agama Islam menurut Ramayulis (2005: 21) adalah upaya dan terencana dalam menyiapkan peserta didik untuk mengenal, memahami, menghayati, mengimani, bertaqwa, berakhlak mulia, mengamalkan ajaran Agama Islam dari sumber utamanya kitab suci Al-Qur'an dan al-Hadist, melalui kegiatan bimbingan, pengajaran, latihan serta penggunaan pengamalan.

\section{HASIL PENELITIAN}

\section{Perencanaan Strategi Pembelajaran Kooperatif Tipe STAD dalam Pembelajaran Kooperatif di SMPN 3 Lengayang}

Proses belajar mengajar adalah proses yang diatur sedemikian rupa menurut langkah-langkah tertentu, agar pelaksanaannya mencapai hasil yang diharapkan. Pengaturan ini dituangkan dalam bentuk perencanaan mengajar, rencana merupakan titik tolak bagi pelaksanaan juga merupakan perintah ke arah kegiatan yang akan dilakukan. Dalam hubungannya dengan pembelajaran, guru membuat perencanaan sebelum melaksanakan pembelajaran di dalam kelas, supaya pembelajaran dapat berjalan dengan terarah dan tercapainya tujuan yang diharapkan. 
Rencana Pelaksanaan Pembelajaran (RPP) adalah suatu perencanaan yang menggambarkan prosedur, suatu rancangan yang dibuat oleh guru sebelum mengajar pada setiap pokok bahasan. Berdasarkan observasi penulis memang semua guru di SMPN 3 Lengayang telah membuat RPP, khususnya guru agama. Sebelum melaksanakan pembelajaran di kelas guru telah menyiapkan segala sesuatunya seperti membuat RPP, menyiapkan materi dan media, agar PBM dapat berjalan dengan lancar.

Dalam pembuatan Rencana Pelaksanaan Pembelajaran (RPP) banyak hal yang dipertimbangkan, apalagi proses pembelajaran pendidikan agama Islam dengan menggunakan strategi pembelajaran kooperatif tipe STAD ini. Guru terlebih dahulu membuat perencanaan yang matang, yaitu dengan melihat pada Standar Kompetensi (SK) dan Kompetensi Dasar (KD) yang terdapat dalam silabus.

Tujuan merupakan komponen utama yang terlebih dahulu dirumuskan guru dalam proses belajar mengajar. Peranan tujuan sangat penting sebab menentukan arah proses belajar mengajar. Apa yang dimiliki siswa semuanya tergantung pada tujuan pembelajaran yang ingin dicapai.

Media adalah pengantar yang memudahkan siswa lebih memahami materi dan nantinya dapat menimbulkan ketertarikan siswa untuk mengikuti proses pembelajaran. Di saat guru melaksanakan proses pembelajaran guru menggunakan media, dan media yang digunakan mempertimbangkan kesesuaian dengan materi dan juga waktu, sehingga dengan adanya media yang mendukung maka diharapkan tujuan pembelajaran mudah tercapai.

$\begin{array}{lcr}\text { Dalam } & \begin{array}{c}\text { langkah } \\ \text { pembelajaran, }\end{array} \\ \text { perencanaan langkah } \\ \text { terakhir yang dipersiapkan guru adalah }\end{array}$ menetapkan bentuk evaluasi yang akan digunakan dalam pelaksanaan pembelajaran yang sesuai dengan tujuan pembelajaran. Informasi yang didapatkan dari responden penelitian bahwa yang dilakukan dalam persiapan penilaian hasil belajar siswa adalah guru menyiapkan instrumen pertanyaan untuk kuis dan format skor kuis siswa.

Di luar perencanaan yang ada dalam Rencana Pelaksanaan Pembelajaran (RPP), perencanaan penting lainnya adalah perencanaan dalam pembentukan kelompok. Jelas bahwa tugas ini bervariasi bergantung kepada tujuan yang ingin dicapai oleh guru untuk suatu pelajaran. Berdasarkan pengamatan penulis pembentukan kelompok dengan strategi pembelajaran kooperatif tipe STAD di SMPN 3 Lengayang ditentukan oleh guru yaitu berdasarkan absensi siswa juga pertimbangan kemampuan akademik siswa.

Rencana Pelaksanaan Pembelajaran (RPP) yang telah dibuat guru untuk pembelajaran kooperatif tipe STAD dirasa belum baik, dikarenakan apa yang tertera di dalam RPP hanyalah berupa lembaran rencana pembelajaran karena pada hakikatnya masih banyak ide yang belum terangkum di dalam RPP, isi serta datadata yang terangkum dalam RPP tersebut belum mampu mencakup semua harapan dari guru yang mengajar.

Berdasarkan dokumen yang diperoleh yaitu berupa Rencana Pelaksanaan Pembelajaran, terlihat RPP yang disusun oleh guru agama tersebut sudah memuat langkah-langkah pembuatan RPP seperti sudah adanya Standar Kompetensi (SK), Kompetensi Dasar (KD), tujuan pembelajaran, materi, metode, langkah-langkah pembelajaran, dan penilaian. Namun pada beberapa langkah tersebut masih ada bagian yang kurang sempurna seperti pada pengorganisasian materi ajar (keruntutan/sistematis materi dengan 
alokasi waktu belum sesuai), kerincian skenario pembelajaran (langkah strategi/metode pada setiap tahap belum tergambar jelas), dan kelengkapan instrumen (kunci jawaban tidak dilampirkan).

\section{Pelaksanaan Strategi Pembelajaran Kooperatif Tipe STAD dalam Pembelajaran PAI di SMPN 3 Lengayang}

Proses belajar mengajar adalah proses yang mengandung rangkaian perbuatan guru dan siswa atas dasar hubungan timbal balik yang berlangsung dalam situasi edukatif untuk mencapai tujuan tertentu. Berlangsungnya proses belajar mengajar merupakan inti dari kegiatan mengajar. Pelaksanaan pengajaran adalah interaksi guru dengan siswa dalam rangka mencapai bahan pelajaran kepada siswa untuk mencapai tujuan pengajaran. Setelah perencanaan tertulis (RPP) disusun selanjutnya diimplementasikan dalam pembelajaran. Pembelajaran merupakan kegiatan inti, untuk itu perencanaan tertulis mempengaruhi keberhasilan pengajaran. Di dalamnya tergambar kegiatan guru dan kegiatan siswa, waktu, media, sumber dan bentuk penilaian. RPP itulah yang akan menjadi acuan guru dalam pelaksanaan pengajaran. Berhasil atau tidaknya pembelajaran tergantung pada guru itu sendiri, apakah guru benar-benar menguasai program pelajaran atau tidak.

Selain mampu membuat Rencana Pelaksanaan Pembelajaran (RPP), guru juga harus mampu mengimplementasikan dalam pembelajaran dengan baik sesuai dengan apa yang telah ditetapkan, agar tujuan pembelajaran berhasil dengan baik. Berdasarkan pengamatan, masing-masing guru khususnya guru bidang studi pendidikan agama Islam di SMPN 3 Lengayang telah mempunyai persiapan tertulis (RPP) untuk materi yang akan diajarkan.
Dalam pelaksanaan pembelajaran seorang guru mampu memilih cara belajar yang baik. Seperti pada pemilihan strategi, metode maupun media yang digunakan. Cara yang digunakan tersebut menimbulkan semangat belajar, siswa tidak bosan, dapat mencapai hasil belajar yang maksimal.

\section{Evaluasi Strategi Pembelajaran Kooperatif Tipe STAD dalam Pembelajaran PAI di SMPN 3 Lengayang}

Tercapai tidaknya tujuan pendidikan dan pengajaran dilakukan usaha atau tindakan evaluasi. Evaluasi memberikan pertimbangan, harga, atau nilai berdasarkan kriteria tertentu. Evaluasi dalam proses pembelajaran merupakan suatu upaya untuk mengetahui segala halhal yang telah dimilki oleh anak didik dari hal-hal yang telah dilakukan guru. Tanpa adanya evaluasi, maka tidak mungkin dapat diketahui hasil belajar siswa. Untuk itu guru melakukan evaluasi berkaitan proses pembelajaran. Berkaitan dengan evaluasi pembelajaran, hal yang sangat penting dimiliki guru adalah menguasai bentuk-bentuk evaluasi.

Dalam kegiatan evaluasi dilihat tiga aspek yaitu kognitif, afektif dan psikomotor. Tes tertulis dalam bentuk essay atau obyektif bisa digunakan untuk ranah kognitif. Kemudian dalam menilai aspek afektif, yang dilihat adalah aktivitas siswa selama proses pembelajaran berlangsung. Begitu juga dengan aspek psikomotor, penilaian dilakukan dalam bentuk tes perbuatan yang terlihat berdasarkan pengamatan guru selama proses pembelajaran.

Pembelajaran kooperatif tipe STAD ini bekerja di bawah struktur penghargaan kooperarif dan karena banyak pelajaran pembelajaran kooperatif bertujuan untuk mencapai pembelajaran kognitif dan sosial yang kompleks, dibutuhkan pendekatan penilaian dan 
evaluasi y ang berbeda, yaitu penskoran nilai dan pemberian hadiah. Dalam penskoran nilai ini terdiri dari tiga langkah, langkah awal pemberian skor dasar untuk tiap siswa, langkah kedua penghitungan skor kuis yaitu setelah masing-masing siswa memperoleh poin dari kuis terkini dan langkah terakhir menentukan skor perkembangan yang ditentukan berdasarkan kriteria tertentu yang telah dijelaskan pada bab sebelumnya.

Setelah diadakan kuis atau melaui proses penskoran, suatu tugas penilaian dan evaluasi penting terakhir yang unik adalah pengakuan terhadap upaya dan hasil belajar siswa, pengakuan ini biasanya dilakukan dengan pemberian penghargaan. Karena siswa akan merasa lebih bangga lagi kalau hasil kerjanya dihargai.

Sehubung dengan penghargaan yang diberikan dalam pembelajaran koooperatif tipe STAD ini dibenarkan oleh seorang siswi dari kelas VII 1 "penghargaan yang diberikan ibu guru pada kami adalah berupa nilai tambahan, hal ini memicu kami untuk jadi kelompok terbaik,".

Kemudian setelah dilaksanakan evaluasi, disana dapat dilihat siswa yang tidak menguasai materi atau tidak aktif dalam proses pembelajaran. Berdasarkan observasi dan informasi yang penulis peroleh dari responden penelitian, hal tersebut dapat dilihat berdasarkan KKM (Kriteria Ketuntasan Minimal), KKM dari pelajaran agama adalah 70 jika nilai berada di bawah KKM maka akan diadakan tindak lanjut berupa remedial. Guru mengadakan remedial di luar jam pelajaran nantinya.

Jadi, berdasarkan uraian di atas dapat disimpulkan bahwa evaluasi yang digunakan dalam pembelajaran kooperatif tipe STAD pada bidang studi Pendidikan Agama Islam di SMPN 3 Lengayang adalah bentuk tes, baik perorangan maupun kelompok. Penilaian dilakukan terhadap tiga aspek yaitu aspek kognitif, afektif dan psikomotor. Bentuk penilaian yang sering digunakan dalam pembelajaran kooperatif tipe STAD ini adalah tes tertulis atau kuis, kemudian tes perbuatan juga pemberian penghargaan bagi kelompok yang memperoleh nilai tertinggi. Jika ada hasil belajar siswa berada di bawah KKM maka guru mengadakan remedial.

\section{KESIMPULAN}

1. Perencanaan strategi pembelajaran kooperatif tipe STAD dalam pembelajaran PAI di SMPN 3 Lengayang belum memenuhi ketentuan seperti pada pengorganisasian materi ajar (keruntutan/sistematis materi dengan alokasi waktu belum sesuai), kerincian skenario pembelajaran (langkah strategi/metode pada setiap tahap belum tergambar jelas), dan kelengkapan instrumen (kunci jawaban tidak dilampirkan).

2. Pelaksanaan pembelajaran kooperatif tipe STAD pada bidang studi PAI di SMPN 3 Lengayang belum sepenuhnya terlaksana. Dari enam langkah-langkah pembelajaran kooperatif tipe STAD, yaitunya pada kerja tim dan kuis. Namun sebagian langkah sudah dilaksanakan oleh guru agama di SMPN 3 Lengayang dengan baik.

3. Bentuk evaluasi pembelajaran koooperatif tipe STAD dalam pembelajaran PAI di SMPN 3 Lengayang adalah tes tertulis atau berupa pemberian kuis. Tes melalui kuis khusus untuk penilaian individu sedangkan penilaian kelompok diambil dari hasil kerja kelompok. Bagi kelompok yang memperoleh nilai tertinggi ada penghargaan berupa nilai tambahan. 
DAFTAR PUSTAKA

Al- Qur'an dan Terjemahannya, Bandung:

Diponegoro, 2000

Al-Maraghi, Ahmad Mustafa, Terjemahan Tafsir Al-Maraghi juz 30, Semarang : PT. Toha Putra, 1985

Djamarah, Syaiful Bahri, Psikologi Pendidikan, Jakarta : Rineka Cipta, 2002

Drajat, Zakiah, Ilmu Pendidikan Islam, Jakarta: Bumi Aksara,1992

Hamka, Tafsir Al Azhar juz VI, Jakarta : Bumi Aksara, 2001

Muhaimin dkk, Strategi Belajar Mengajar, Penerapan dalam Pembelajaran Agama, Surabaya: Citra Media, 1996

Mukhtar, Desain Pembelajaran Pendidikan Agama Islam, Jakarta: Misaka Galiza, 2003

Nawawi, Hadari, Penelitian Terapan, Yogyakarta: Gajah Mada Universitas, 1996

Nizar, Samsul, Filsafat Pendidikan Islam, Jakarta : Ciputat Press, 2002

Ramayulis, Ilmu Pendidikan Islam, Jakarta: Kalam Mulia, 2002 .Pengantar Psikologi Agama, Jakarta: Kalam Mulia, 2002

Riduwan, Rumus dan Data dalam Analisis Statistika, Bandung: Alfabeta, 2010

Rusman, Model-model Pembelajaran: Mengembangkan Profesionalitas Guru, Jakarta: Rajawali Pers, 2001
Sanjaya, Wina, Kurikulum dan Pembelajaran, Jakarta : Kencana Prenada Media Group, 2008

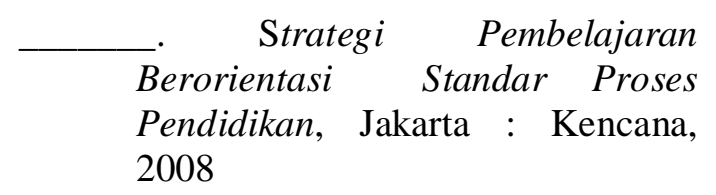

Slavin, Robert, Cooperative Learning, Theory, Research and Practice, Penterjemah Narulita Yusron, Bandung: Nusa Media, 2005

Silberman, Melvin L, 101 strategies to teach any subject, Penterjemah Raisul Muttaqin, Bandung : Nusamedia, 2006

Sudjana, Nana, Dasar-dasar Proses Pembelajaran, Bandung : Sinar Baru Grafindo, 2009

Suryabrata, Sumadi, Metode Penelitian, Jakarta : Rajawali, 1991

Trianto, Mendesain Model Pembelajaran Inovatif, Progresif : Konsep, Landasan, dan Implementasinya pada Kurikulum KTSP, Jakarta: Kencana, 2009

UU SISDIKNAS NO 20 Tahun 2003, Jakarta : Sinar Grafika, 2003

Wina, Made, Strategi Pembelajaran Inovatif Kontemporer, Jakarta : Bumi Aksara, 2009

Yunus, Mahmud, Metode Khusus Pendidikan Agama Islam, Jakarta: PT Hidakarya Agung 